\title{
Spatial Modeling of Relationship Between Soil Erosion Factors and Land-use Changes at Sub- Watershed Scale for the Talar Watershed, Iran
}

Fahimeh Mircholli

Tarbiat Modares University

Maziar Mohammadi Khanghah

Tarbiat Modares University

Seyed Hamidreza Sadeghi ( $\nabla$ sadeghi@modares.ac.ir)

Tarbiat Modares University https://orcid.org/0000-0002-5419-8062

\section{Research Article}

Keywords: Albourzian Watershed, Soil Degradation, Regression Analysis, Remote Sensing, Spatial Nonstationarity

Posted Date: May 24th, 2021

DOI: https://doi.org/10.21203/rs.3.rs-505697/v1

License: (c) (i) This work is licensed under a Creative Commons Attribution 4.0 International License. Read Full License 
$5{ }^{1}$ Former Ph.D. Student, Department of Watershed Management Engineering, Faculty of

$6 \quad$ Natural Resources and Marine Sciences, Tarbiat Modares University, Iran

$7 \quad$ E-mail: $\underline{\text { f.mirchooli@modares.ac.ir }}$

\section{Spatial Modeling of Relationship between Soil Erosion Factors and Land-Use Changes} at Sub-Watershed Scale for the Talar Watershed, Iran

Fahimeh Mirchooli ${ }^{1}$, Maziar Mohammadi Khanghah ${ }^{2}$ and Seyed Hamidreza Sadeghi ${ }^{3}$

${ }^{2}$ Former Ph.D. Student, Department of Watershed Management Engineering, Faculty of Natural Resources and Marine Sciences, Tarbiat Modares University, Iran

E-mail: maziarmohammadi@modares.ac.ir

${ }^{3}$ Professor (Corresponding Author), Department of Watershed Management Engineering, Faculty of Natural Resources and Marine Sciences, Tarbiat Modares University, Noor 4641776489, Mazandaran Province, Iran

E-mail: sadeghi@modares.ac.ir; Tel. (Fax): +98 1144998123

\section{Abstract}

Soil erosion is one of the most common types of land degradation. To provide useful information for proper management, quantitative soil erosion evaluation and identification of effective factors are needed. However, rare studies have been reported on spatial modeling of soil erosion in connection with affective factors to prioritize the locality and the type of erosion control measures Hence, the aim of this study was to (1) assess erosion-prone areas in the Talar Watershed, Iran, using the Revised Universal Soil Loss Equation (RUSLE) model, and (2) investigate the relationship between soil erosion variability and land-use changes. Toward that, the ordinary least squares (OLS), geographically weighted regression (GWR) models, and Principal Component Analysis (PCA) were used to analyze spatial relationships between soil erosion, and land-use, and the RUSLE factors. The results of the OLS and GWR models indicated these relationships are spatially non-stationary and GWR models had a good predictive performance rather than OLS with lower Akaike's Information Criterion (from 254.31 to 276.81 in OLS, and from 247.87 to 269.42 in GWR) and higher adjusted $\mathrm{R}^{2}$ values (from 0.12 
to 0.54 in OLS, and from 0.36 to 0.66 in GWR). Among the aforementioned variables, LS factor, $\mathrm{P}$ factor, forest, and irrigated land were the most effective variables in GWR models. The results of PCA showed PC1 and PC2 explained $66.2 \%$ of the variation in soil erosion concerning land-use and the RUSLE factors. These results provided appropriate references for managers and experts in the proper planning of the study watershed.

Keywords: Albourzian Watershed; Soil Degradation; Regression Analysis; Remote Sensing; Spatial Nonstationarity

\section{Introduction}

Soil erosion is one of the most serious environmental issues that is linked to land degradation. As a result, soil erosion is the primary cause (> 85\%) of land loss (Tang et al., 2015). It causes some direct on-site and off-site problems such as soil nutrient loss, reduced agricultural productivity, land abandonment (Nunes et al., 2011; Ochoa et al., 2016; De Long et al., 2019), and some secondary environmental problems viz. flooding, river siltation, and water pollution (Chakrabortty et al. 2020). Furthermore, Soil erosion is an environmental threat to sustainable development. Water erosion affects some 1100 Mha of land worldwide which is almost twice what occurred by wind erosion (Ganasri and Ramesh 2016). As a result, for effective soil and water conservation and adaptation of certain management strategies, monitoring, and estimation of water erosion, as well as identification of critical areas for the implementation of managerial practice and technical measures, are needed. Remote sensing (RS) technology together with the Geographical Information Systems (GIS) provides some valuable information to help policymakers make sound planning decisions about implementing erosion control strategies, while it remains the most effective and time-consuming method. Many models, such as the Soil and Water Assessment Tool (SWAT) (Halecki et al., 2018), the Water Erosion Prediction Project (WEPP) (Anache et al., 2018), the Universal Soil Loss Equation (USLE) (Gia et al., 2018), the Revised Universal Soil Loss Equation (RUSLE) (Chicas et al., 2016), and Erosion Productivity Impact Calculator (EPIC) (Gao et al., 2017) have been developed in this way for risk evaluation or predictive assessment of water erosion. Each model has its own set of features and implementation possibilities. The RUSLE and its previous version (USLE) are accepted universally, because of reasonable costs, applicability, and reliability of results which has been corroborated as one of the best and most widely used models for estimating soil erosion (Prasannakumar et al., 2011; Fayas et al., 2019; Efthimiou et al., 2020). 
RUSLE predicts soil loss using rainfall erosivity, topography, soil erodibility, and vegetation cover and practice management, which will be effective for better understanding the erosion process. Many researchers have shown that soil erosion is influenced by some other factors such as characteristics of soil particle size distribution (Wang et al., 2008), different crop types (Ruysschaert et al., 2007), and land-use (De Long et al., 2019; Vanacker et al., 2019). Changes in the land-use distribution pattern, known as landscape and land-use morphology, can also affect soil erosion. Soil erosion is influenced by both land-use types and landscape morphology.

Some researchers have applied traditional statistical analysis and ordinary least squares (OLS) model to explore relationships among dependent and independent factors, as a result, the relationships are spatially consistent across the entire study area. In the other words, these traditional statistical methods provide average and global relationships, which may neglect some significant spatial characteristics and may hide local variations. Generating a global relationship shows the average conditions while local variations of parameters are ignored. In this light, advanced approaches can be used to address current limitations and assess spatial heterogeneity in relationships. In this vein, a local statistical model called geographically weighted regression (GWR) was proposed by Brunsdon et al. (1996) to determine the spatial non-stationary relationships. This technique provides spatially weighting information, which enables the regression models to be various locally.

In the past, GWR and OLS have been used in a variety of fields including the ecology and even human geography (Tu 2011), NDVI-rainfall relationship (Georganos et al., 2017), land use, and land cover (Dadashpoor et al., 2019), soil organic carbon (Mirchooli et al., 2020a), land surface temperature (Li et al., 2020; Zhao et al., 2018a; Mirchooli et al., 2020b). Many studies investigated the relationships among soil erosion, and the RUSLE factors and land-uses using commonly global statistical models (Mehri et al., 2018; Setyawan et al., 2019; Nyesheja et al., 2019). A review of the current literature reveals that the majority of studies used a single model to apply soil erosion and other driving forces variables to all data, which was uniformly distributed throughout the entire study area. To achieve an acceptable result, research on the spatial non-stationary relationship among soil erosion, and different variables is necessary for better understanding these relationships. Therefore, the main goals of the current research are to 1) assess the spatial distribution of soil erosion for the Talar Watershed, Iran using the RUSLE model, 2) assess local spatial distributions of soil erosion using cluster analysis and classify similar sub-watersheds, and 3) identify spatial variations of soil erosion in response to the land-use area and the RUSLE factors using PCA, OLS, and GWR models. 


\section{Materials and Methods}

\subsection{Study area}

The Talar Watershed in eastern Mazandaran Province, north of Iran, was used as a case study for this study. It is located at 3636 to $3646 \mathrm{~N}$ and 5523 to $5431 \mathrm{E}$ with an area of ca. 211000 ha. Talar is one of the most significant rivers draining into the Caspian Sea. The Talar watershed has been subjected to a variety of human interventions, including fuel, timber smuggling, livestock grazing, road construction, mine exploitation, and factory development (Kavian et al., 2018) leading to serious threats to the water quality and soil condition in the watershed. The Talar River with 100 km length intersects the Kassilian River with a length of $50 \mathrm{~km}$ (Talar). With mean annual precipitation of $552.7 \mathrm{~mm}$, the climate in this watershed is semi-humid and cold. The annual mean minimum and maximum temperatures are 7.7 and $21.1^{\circ} \mathrm{C}$, respectively. This watershed is characterized by gentle steep hill slopes $(<12 \%)$ which lie between the southeast highland plains and land at the vicinity of the watershed outlet. Highlands and sloping areas (> 60\%) comprise $14.2 \%$ of the total area, while inclinations of more than $30 \%$ constitute $38 \%$. (Mohammadi et al., 2019). Fig. 1 presents the general geographical view of the location and other important information of the Talar Watershed in the north of Iran and Mazandaran Province. In this watershed, the lands were natural forest, but the land-use change occurred by the local people and industries as well. In this watershed, the natural forest was converted to agricultural and pasture lands made the watershed more vulnerable to soil erosion. The main land-uses are Forest, rangeland, dry farming, irrigated agriculture, residential area (Mohamadi et al., 2016).

To achieve the goals of the study, remote sensing data and input data of the RUSLE model were processed to obtain a land-use map and soil erosion. Three models of PCA, OLS, and GWR were used to investigate the relationships among soil erosion, and the RUSLE factors, and land-uses. The flowchart presented in Fig. 2 shows the proposed method in this study.

Fig. 1

Fig. 2

\subsection{Data pre-processing}

Land-use distribution map of Talar watershed was obtained using Landsat 8/Operational Land Imager (OLI) image (02.07.2014) and supervised classification algorithm in the ENVI 5.3 software environment (Torabi Haghighi et al., 2018). Five land-use classes were identified including forest, rangeland, irrigated agriculture, rainfed agriculture, and residential area. To meet the requirement for the RUSLE model, the monthly 

model was downloaded from www.earthexplorer.usgs.gov to computed the LS factor. In addition, to prepare K factor inputs, 140 points of soil samples were collected based on homogeneous land units resulting from overlying soil types, land-use/cover, and slope layers. After that, the necessary geo-referenced, radiometric, and FLAASH atmospheric corrections were made. In addition, the Talar Watershed's land-use map was generated using supervised classification and maximum likelihood algorithm. Some point samples of 1250 were collected during the field survey and divided into two sets of validation and training with respective values of 30 and $70 \%$. The error matrix, as well as the accuracy of the producer and the accuracy of the user, were used to determine the overall accuracy of land-use.

\subsection{Soil erosion estimation}

129 The RUSLE model is used as the simplest model to estimate soil erosion in this analysis. Eq. (1) was used to measure the mean annual soil loss (A) (Renard et al., 1991):

$$
A=R \times K \times L S \times C \times P
$$

131

where $R$ is rainfall erosivity factor $\left[\mathrm{MJ} \mathrm{mm},\left(\mathrm{ha}^{-1} \mathrm{~h}^{-1}\right.\right.$ year $\left.{ }^{-1}\right)$ ]; $K$ is the soil erodibility factor [ton ha ${ }^{-1} \mathrm{~h} \mathrm{MJ}^{-1} \mathrm{ha}^{-1}$ $\left.\mathrm{mm}^{-1}\right] ; L S$ is the slope length and steepness factor (dimensionless); $C$ is the cover management factor (dimensionless), and $P$ is the conservation support or erosion control practices factor (dimensionless).

Rainfall erosivity (R): $\mathrm{R}$ factor reflected the soil erosion potential caused by rainfall was calculated using the Renard and Freimund (1994) method according to Eqs. (2) to (4):

$$
\begin{aligned}
& R=0.7397 F^{1.847}, F<5 \mathrm{~mm} \\
& R=95.77-6.081 F+0.477 F^{2}, F>55 \mathrm{~mm} \\
& F=\sum_{i=1}^{12} P_{i}^{2} / \bar{P}
\end{aligned}
$$

In which $F$ is the modified index value, $P_{i}$ is average monthly precipitation $(\mathrm{mm}), \bar{P}$ is average annual precipitation $(\mathrm{mm})$.

Soil erodibility (K): The Wischmeier and Smith equation was used to determine the soil erodibility factor in this analysis (Eq. 5) (Wischmeier 1976).

$$
100 K=2.1 M^{1.14} \times 10^{-4} \times(12-\% O M)+3.25(S-2)+2.5(P-3)
$$


where $K$ is the Soil erodibility factor, $M$ is the particle size parameter (\% silt + \%very fine sand) * (100 - \% clay), $O M$ is the organic matter content $(\%), \mathrm{S}$ and $\mathrm{P}$ are the classes for soil structure and permeability, respectively.

Topographic factor (LS): LS factor reflects the combined impact of slope length (L) and steepness (S) on soil erosion. In this study, a program is written in Arc Macro Language (ALM) (Hickey 2000) updated in 2004 with the $\mathrm{C}^{++}$programming language (http://www.iamg.org), was applied to calculate the LS factor.

Land cover management $(\mathbf{C})$ : The protective impact of ground covers against erosive rainfall i.e., $\mathrm{C}$ factor was calculated using Normalized difference vegetation index (NDVI) according to Eq. (6)(Nearing et al., 1989) :

$$
C \text { Factor }=0.407-0.5953 \times N D V I
$$

Conservation practices factor $(\mathbf{P})$ : The relevant $\mathrm{P}$ factor value was calculated in this study using a method proposed by Troeh et al. (1980), which was partly based on land-use data.

\subsection{Spatial modeling}

\subsubsection{OLS and GWR models}

To understand the importance of the RUSLE factors and land-uses in the estimated soil erosion, and the spatial relationships among them, the OLS and GWR models were applied in the present study.

OLS is the primary statistical and global model and examines the average condition over the space as shown in Eq. (7).

$y=\beta_{0}+\sum_{j=1}^{n} \beta_{j} x_{i}+\varepsilon$

where $\mathrm{x}_{\mathrm{i}}$ is the independent variables (i.e., RUSLE factors and land-use areas) and $\mathrm{y}$ is the dependent variable (i.e., soil erosion); $\mathrm{n}$ is the number of independent variables; $\beta_{0}$ is intercept and $\beta_{\mathrm{i}}$ and e represent respectively coefficient and error.

Whilst, the GWR model is a local form of linear regression that overcomes the limitation of the OLS model. This model improves the results of OLS by recognizing the spatial variation in the relationship among the variables. GWR improve the OLS model by considering the local parameters estimate for each observation $\mathrm{i}$ as expressed in Eq. (8):

$y_{i}=\beta_{0}\left(u_{i}, v_{i}\right)+\sum_{j=1}^{n} \beta_{j}\left(u_{i}, v_{i}\right) x_{i j}+\varepsilon_{i}$ 
where $y_{i}$ is the value of the soil erosion at location $i,\left(u_{i}, v_{i}\right)$ is the spatial location of $i^{\text {th }}$ data, $\beta_{0}\left(u_{j}, v_{j}\right)$ acts as intercept, and $\beta_{\mathrm{j}}\left(\mathrm{u}_{\mathrm{i}} . \mathrm{v}_{\mathrm{i}}\right)$ is the value of the $\mathrm{j}^{\text {th }}$ parameter at the location of $\mathrm{i}, \varepsilon_{i}$ is the random error for location $\mathrm{i}$ (Georganos et al., 2017).

The location distance $\mathrm{i}$ is used to measuring the weight of data which varies with $\mathrm{i}$. The parameters in a matrix form at location i are estimated with the help of Eq. (9):

$\hat{\beta}\left(u_{i}, v_{i}\right)=\left[X^{T} W\left(u_{i}, v_{i}\right) X\right]^{-1} X^{T} W\left(u_{i}, v_{i}\right) Y$

where $\mathrm{W}\left(\mathrm{u}_{\mathrm{i}}, \mathrm{v}_{\mathrm{i}}\right)$ is a spatial weighting matrix, $\mathrm{X}$ is an independent data (i.e., RUSLE factors, and land-use areas) matrix and $\mathrm{Y}$ is a soil erosion data vector (Fotheringham et al., 2002; Gao and Li, 2011).

Although several functions have the potential to be used for determining the weighting matrix, the common method of Gaussian function was applied to calculate the weight of each point using Eq. (10):

$w_{i j}=e^{-0.5\left(d_{i j} / h\right)^{2}}$

where $\mathrm{W}_{\mathrm{ij}}$ is the weight of observation at location $\mathrm{j}$ for estimating the dependent variable at location $\mathrm{i}$, and $\mathrm{h}$ is a bandwidth.

Wang et al. (2005 and 2006) regressed this equation as a distance decay function, which means that the higher the weight of position $\mathrm{j}$, the closer it is to location $\mathrm{i}$. In the GWR model, the maximum distance from location $\mathrm{i}$ as bandwidth controlled the size of the neighborhood was considered. The fixed kernel appropriate for little data with evenly distributed in space (Georganos et al., 2017; Taghipour Javi et al., 2014) was used for developing the GWR model in the current research.

In the present study, OLS and GWR were conducted in ArcGIS 10.3. Finally, adjusted $\mathrm{R}^{2}$ and Akaike's Information Criterion (AIC) were used to measure and compare the accuracy and performance of these models, in which the higher adjusted $\mathrm{R}^{2}$ and lower AIC means, the better performance of the model.

\subsubsection{Principal component analysis}

Principal Component Analysis (PCA), a multivariate statistical technique, was used to provide information about the most important factors and to describe the variance of the data (Pejman et al. 2015). In the present study, the PCA approach was used to analyze the relationship between soil erosion, land-use, and the RUSLE factors, and verify the key potential factor of soil erosion in the studied region, using R software, FactoMineR, and factoextra packages.

\section{Results and Discussion}


The value of the $\mathrm{R}$ factor was ranged from 209.65 to $503.24\left(\mathrm{MJ} \mathrm{mm} \mathrm{ha}{ }^{-1} \mathrm{~h}^{-1} \mathrm{y}^{-1}\right.$ ) across the study watershed that the highest and lowest values were distributed in the northern and western parts of the watershed, respectively. The mean value of this factor was $308.25 \mathrm{MJ} \mathrm{mm} \mathrm{ha-1} \mathrm{h}^{-1} \mathrm{y}^{-1}$ which along with the results of Sadeghi and Tavangar (2015). In the case of the $\mathrm{K}$ factor, values were distributed between 0.02 and 0.09 with the highest values in central areas. The values of the LS factor varied from some 0.00 to 140.82 following flow accumulation and slope steepness. The values of the $\mathrm{C}$ factor were found to be between 0.24 and 0.46 . Ultimately, the $\mathrm{P}$ factor ranged from 0.10 to 0.70 . The spatial distribution of soil loss based on RUSLE is illustrated in Fig. 4.

Soil erosion potential was then divided into three categories of low, moderate, and strong. Low soil erosion is observed in most areas of the watershed, especially in the east and southeast. Soil erosion is most prevalent in the central parts of the watershed, where almost all affective factors are high except $\mathrm{R}$.

Fig. 3

To assess soil erosion for the Talar Watershed, enhanced hierarchical Cluster analysis based on Euclidean distance was adapted to cluster data of soil erosion in the sub-watersheds.

Cluster analysis generated a dendrogram, grouping all 34 sub-watersheds into two major clusters of subwatersheds. In one group, all sub-watersheds with a low level of soil erosion are clustered together. The other group includes sub-watersheds with a high level of soil erosion which can be further subdivided into three additional clusters. The results of cluster analysis are shown in Fig. 4.

Group 1 consisted of sub-watersheds 5, 1, 2, 3, 7, 8, 10, 11; group 2 included sub-watersheds 27, 30, 34, 32, 33; and group 3 comprised sub-watersheds $14,15,17,18,4,6,9,12,13$, and group 4 included remained subwatersheds of the Talar Watershed. The sub-watersheds in the same group have similar characteristics in terms of soil erosion. In the case of group 1, these sub-watersheds were located near the outlet of the watershed were mainly influenced by dense forest cover (i.e., lower $\mathrm{C}$ factor) and the least human interferes and good land-use (i.e., lower P factor).

Fig. 4

\subsection{Development of OLS and GWR models}


In this research, different variables including areas of some land-use types viz. rainfed agriculture, forest,

223

224

225

226

227

228

229

230

231

232

233

234

235

236

237

238

239

240

241

242

244

245

246

247

248

irrigated agriculture, rangeland, urban, $\mathrm{R}$ factor, $\mathrm{K}$ factor, LS factor, $\mathrm{C}$ factor, and $\mathrm{P}$ factor were used to predict soil erosion using OLS and GWR for the Talar Watershed.

The OLS models were conducted before the GWR models. The analysis of OLS statistics namely Jarque-Bera Statistic showed that it was not significant ( $\mathrm{p}$ values=0.26-0.87) for all variables which meant the residuals were not normally distributed. The normal distribution of residual indicated that the model was biased and missed some key effective variables. Moreover, For the studied variables, the joint F-statistics were significant (p-value $<0.05)$, meaning that the relationship between the dependent and independent variables was non-stationary and that the GWR model might boost it. The variables of urban and rainfed agriculture areas with Jarque-Bera Statistic and Joint F-statistics of respective p-values of $<0.05$ and $>0.05$, were removed from further analyses.

The adjusted R-squared $\left(\mathrm{R}^{2}\right)$ and AICs were used to compare the model performances. So that, the models with higher adjusted $\mathrm{R}^{2}$ and lower AICs were considered as better performed models. In the OLS model, among the areas of land-uses variables, area of forest and irrigated farming were the most effective variables with adjusted $\mathrm{R}^{2}$ and AICs values of $0.29,269.20$, and 0.14 and 275.99 , respectively. The detailed results are shown in Table 1. Furthermore, model (10) of the $\mathrm{P}$ factor following by model (8) of the $\mathrm{C}$ factor were the most important factors among other models of the RUSLE factors in the OLS models.

GWR statistics are shown in Table 1 also explained that the higher variance and lower AIC values rather than OLS models in all studied models which confirmed the results of other researchers in other fields (Zhao et al., 2018b; Dadashpoor et al., 2019; Li et al., 2020). The variable of the irrigated land farming area had the greatest effect with the least AIC and maximum adjusted $\mathrm{R}^{2}$.

\section{Table 1}

The outputs of the GWR model offered a spatial illustration of the independent variables in describing soil erosion in the Talar Watershed. The spatial pattern of local adjusted $\mathrm{R}^{2}$ for independent variables is shown in Fig. 5. It indicated that local $\mathrm{R}^{2}$ was not homogeneously distributed for the Talar Watershed. Most local adjusted $\mathrm{R}^{2}$ values for the $\mathrm{K}$ factor were less than 0.50 , suggesting that the $\mathrm{K}$ factor was linked to soil erosion in the southern regions of the study watershed. The $\mathrm{K}$ factor had positive regression coefficients, which indicated that an increase in $\mathrm{K}$ factor could result in a soil erosion increase, and the influence was higher in the northern and central sub-watersheds. 
In almost all sub-watersheds, the LS factor can explain more than $26 \%$ of the spatial variation in soil erosion.

253

254

255

256

257

258

259

260

261

262

263

264

265

266

267

268

269

270

271

272

273

274

275

276

277

278

279

280

281

Some researchers have also reported similar findings of the important impact of topography on soil erosion (Nazari and Mohammady, 2017; Chalise et al., 2018). The increase in LS factor affected the soil erosion more strongly in the northern and central sub-watersheds with a local regression coefficient of 4.59-5.29, which meant the change of LS factor could increase the soil erosion up to a maximum level of $459 \%-529 \%$ in local areas.

From the north to the south of the watershed, the local adjusted $\mathrm{R}^{2}$ for the $\mathrm{C}$ factor was found to be decreasing. As a result, the $\mathrm{C}$ factor had a greater effect on soil erosion in the upper parts of the watershed than it did in the lower parts. Similarly, the highest local adjusted $\mathrm{R}^{2}$ of the $\mathrm{P}$ factor was obtained for sub-watersheds located at the northern part of the watershed. Generally, it can be explained that among the RUSLE factors, LS and P factors had a large impact on soil erosion due to topographic characteristics of the Talar Watershed, and suitable protective measurement in most parts of the watershed.

These local variations in local adjusted $\mathrm{R}^{2}$ for the $\mathrm{P}$ factor showed that the spatial trends of the $\mathrm{P}$ factor were better associated with soil erosion in some northern parts of the watershed, while correlations in the southern parts were weaker. In the sub-watersheds 32 and 34 , the $\mathrm{P}$ factor was negatively associated with soil erosion, and the largest value of the local coefficient was found in the north of the Talar watershed.

Fig. 5

The local coefficient and local adjusted $\mathrm{R}^{2}$ distributions of the land-use for soil erosion in the GWR models are shown in Fig. 6. As indicated, the northern and central parts of the watershed with the most area of irrigated land had higher values of local adjusted $\mathrm{R}^{2}$. The global coefficient for irrigated land, on the other hand, was -0.04 , suggesting a negative relationship between soil erosion and irrigated land areas. The local map of irrigated land coefficients, however, showed a range of -0.059 to 0.154 , indicating the spatial heterogeneity of the model. The relationships between soil erosion and areas of irrigated land had complex local characteristics. The sign of the local coefficients for this variable switched from positive in the southeastern sub-watersheds to negative in the other sub-watersheds. Cropping systems, mainly wheat cultivated on sloping lands with intrinsic high soil erodibility, represented the prone areas of the watershed to soil loss among different irrigated lands and caused a positive relationship with soil erosion.

For forest land-use, an obvious spatial correlation between forest area and soil erosion had been determined by local adjusted $\mathrm{R}^{2}$ values. The local adjusted $\mathrm{R}^{2}$ in the northern sub-watershed was greater than those of southern 
parts of the watershed due to the greater presence of forestlands in this part of the watershed. Forestland had negative regression coefficients that indicated that a decrease in the area of the forest could increase soil erosion. This close relationship between forestland and soil erosion had also been verified by other research (Koirala et al., 2019; Belayneh et al., 2019; Jazouli et al., 2019). In the term of local adjusted $\mathrm{R}^{2}$ and coefficient of rangeland areas, southern parts of the watershed showed a weaker correlation with soil erosion rather than northern parts. However, the rangeland mostly covers the southern sub-watersheds. This could be attributed to rangeland conditions, which are more degraded in the northern sub-watersheds than southern parts.

The result of the GWR model showed a meaningful relationship between soil erosion and land-uses for the Talar Watershed, particularly for forestland. In this way, studies reported that land-use is an important factor that exacerbates the roles of rainfall and slope steepness on soil erosion processes (Thornes et al., 1990; Thornes and Wainwright, 2004). In the last two decades, a large area of the Talar watershed turned to agriculture through deforestation and land conversion (Kavian et al., 2018) leading to dramatic soil erosion as confirmed by other researchers (e.g., Chaplot et al., 2005).

Fig. 6

\subsection{Principle component analysis (PCA)}

The scree plot obtained from PCA analysis revealed ten principal components (PCs) in soil erosion prediction as shown in Fig. 7. In total, PC1 and PC2 explained $66.2 \%$ of soil erosion resulted from the RUSLE model concerning land-use and the RUSLE factors, which gave a good idea of data structure. PC1 and PC2 represented $40.7 \%$ and $25.5 \%$ of the total variance for soil erosion about explanatory variables, respectively. The contribution of different explanatory variables in PC1 and PC2 of soil erosion is indicated in Fig. 8.

Based on Fig, 8, as the arrows change from bright blue and shorter ones to a darker blue and longer ones, it is inferred that the contribution of variables in studied PCs increased. Some variables viz. forest, irrigated agriculture, and urban had obvious correlations and higher contributions with dimension 1 ( $\mathrm{p}$-values $<0.01$ ). 
312 Previous researches (Sharma et al., 2011; Park 2012; Zare et al., 2017) confirmed the important role of 313 forestland on soil erosion, and the impact of traditional farming systems in irrigated land of the Talar Watershed.

314 As shown in Table 2, among different land-uses, forest and irrigated agriculture had a significant positive relationship with soil erosion, which is due to the presence of dense vegetation cover and its protective role. Furthermore, it is found the strong negative contribution and correlation for $\mathrm{P}$ factor $(-0.82)$ and $\mathrm{C}$ factor $(-0.78)$ in dimension 1 (Dim1), which meant proper land cover management and conservation practices could reduce soil erosion significantly as documented by Tang et al. (2015) and Thomas et al. (2018). In the case of dimension 2 (Dim2), it was characterized by a positive higher correlation between rainfed agriculture and the $\mathrm{K}$ factor in the RUSLE model. Adversely, the R factor was negatively associated with Dim2 (p-values $<0.01)$.

Table 2

\section{Conclusion}

The spatial relationships between soil erosion, land use, and the RUSLE factors were investigated using OLS and GWR. The results of these models were compared, and it was found that all GWR models outperformed their OLS counterparts in terms of modified $\mathrm{R}^{2}$ and AIC values, as well as providing more details through the use of a local coefficient. In the other words, GWR was more effective and powerful for interpreting the relationship between soil erosion and explanatory variables. The relationships provided by the GWR models revealed significant spatial non-stationarity. The association between soil erosion was stronger with LS factor, P factor, and forestland. The LS factor had positive relationships with soil erosion. The results of PCA also showed PC1 and PC2 could explain some $66.2 \%$ of the variance, and forest and irrigated lands had an obvious correlation and higher contribution with variables associate with dimension1. Forest had negative relationships with soil erosion, so it was related to the obstacle role of vegetation cover against erosion. The current study indicated how to use GWR to integrate effective factors in soil erosion and improve our understanding of their spatial distribution at the regional scale. The findings of the current research provided valuable information for assessing and managing soil erosion, as well as identifying areas in the studied watershed that need immediate conservation measures. 
342 The authors declare that they have no known competing financial interests or personal relationships that could

343 have appeared to influence the work reported in this paper.

345 Funding

346 The partial support of the Agrohydrology Research Group of Tarbiat Modares University (Grant No. IG-39713),

347 Iran, concerning the corresponding author is acknowledged.

348

349 Conflict of interest

350 The authors declare no conflict of interest.

351

352

\section{Availability of data and materials}

353

The datasets used and analyzed during the present study are available from the corresponding author on reasonable request.

355

356

Code availability

357

R software was used for this study.

358

359

360

361

362

363

364

365

366

367

368

369

370

371

\section{Author Contributions}

All authors contributed to the study's conception and design. Material preparation, data collection, and analysis were performed by Fahimeh Mirchooli and Maziar Mohammadi Khanghah. The first draft of the manuscript was written by Fahimeh Mirchooli and Maziar Mohammadi Khanghah, and Seyed Hamidreza Sadeghi commented on original versions of the manuscript. All authors read and approved the final manuscript. Seyed Hamidreza Sadeghi reviewed and edited the final manuscript.

\section{References}

Anache JAA, Flanagan DC, Srivastava A, Wendland EC (2018) Land use and climate change impacts on runoff and soil erosion at the hillslope scale in the Brazilian Cerrado. Science of the Total Environment 622623:140-151. https://doi.org/10.1016/j.scitotenv.2017.11.257

Belayneh M, Yirgu T, Tsegaye D (2019) Potential soil erosion estimation and area prioritization for better conservation planning in Gumara watershed using RUSLE and GIS techniques '. Environmental Systems Research 8:1-17. https://doi.org/10.1186/s40068-019-0149-x 
Chakrabortty R, Pal SC, Sahana M, et al (2020) Soil erosion potential hotspot zone identification using machine learning and statistical approaches in eastern India. Natural Hazards 104:1259-1294. https://doi.org/10.1007/s11069-020-04213-3

Chalise D, Kumar L, Prasad C, Sushil S (2018) Spatial assessment of soil erosion in a hilly watershed of Western. Environmental Earth Sciences 77:1-11. https://doi.org/10.1007/s12665-018-7842-3

Chaplot V, Giboire G, Marchand P, Valentin C (2005) Dynamic modelling for linear erosion initiation and development under climate and land-use changes in northern Laos. Catena 63:318-328

Chicas SD, Omine K, Ford JB (2016) Identifying erosion hotspots and assessing communities ' perspectives on the drivers, underlying causes and impacts of soil erosion in Toledo's Rio Grande Watershed : Belize. Applied Geography 68:57-67. https://doi.org/10.1016/j.apgeog.2015.11.010

Dadashpoor H, Azizi P, Moghadasi M (2019) Environment Land use change, urbanization, and change in landscape pattern in a metropolitan area. Science of the Total Environment 655:707-719. https://doi.org/10.1016/j.scitotenv.2018.11.267

Efthimiou N, Lykoudi E, Psomiadis E (2020) Inherent relationship of the USLE, RUSLE topographic factor algorithms and its impact on soil erosion modelling. Hydrological Sciences Journal ISSN: https://doi.org/10.1080/02626667.2020.1784423

Fayas CM, Abeysingha NS, Nirmanee KGS, et al (2019) Soil loss estimation using RUSLE model to prioritize erosion control in KELANI river basin in Sri Lanka. International Soil and Water Conservation Research 7:130-137. https://doi.org/10.1016/j.iswcr.2019.01.003

Ganasri BP, Ramesh H (2016) Assessment of soil erosion by RUSLE model using remote sensing and GIS - A case study of Nethravathi Basin. Geoscience Frontiers 7:953-961. https://doi.org/10.1016/j.gsf.2015.10.007

Gao J, Li S (2011) Detecting spatially non-stationary and scale-dependent relationships between urban landscape fragmentation and related factors using Geographically Weighted Regression. Applied Geography 31:292-302. https://doi.org/10.1016/j.apgeog.2010.06.003

Gao L, Bowker MA, Xu M, et al (2017) Biological soil crusts decrease erodibility by modifying inherent soil properties on the Loess Plateau, China. Soil Biology and Biochemistry 105:49-58. https://doi.org/10.1016/j.soilbio.2016.11.009

Georganos S, Abdi AM, Tenenbaum DE, Kalogirou S (2017) Examining the NDVI-rainfall relationship in the semi-arid Sahel using geographically weighted regression. Journal of Arid Environments 146:64-74. 
https://doi.org/10.1016/j.jaridenv.2017.06.004

403

404

405

406

407

408

409

410

411

412

413

414

415

416

417

418

419

420

421

422

423

424

425

426

427

428

429

430

431

Gia T, Degener J, Kappas M (2018) Integrated universal soil loss equation ( USLE ) and Geographical Information System ( GIS ) for soil erosion estimation in A Sap basin : Central Vietnam. International Soil and Water Conservation Research 6:99-110. https://doi.org/10.1016/j.iswcr.2018.01.001

Halecki W, Kruk E, Ryczek M (2018) Land Use Policy Loss of topsoil and soil erosion by water in agricultural areas : A multi-criteria approach for various land use scenarios in the Western Carpathians using a SWAT model. Land Use Policy 73:363-372. https://doi.org/10.1016/j.landusepol.2018.01.041

Hickey R (2000) Slope angle and slope length solutions for GIS. Cartography 29:1-8

Jazouli A El, Barakat A, Khellouk R, et al (2019) Remote sensing and GIS techniques for prediction of land use land cover change effects on soil erosion in the high basin of the Oum Er Rbia River. Remote Sensing Applications: Society and Environment 13:361-374. https://doi.org/10.1016/j.rsase.2018.12.004

Kavian A, Mohammadi M, Gholami L, Rodrigo-Comino J (2018) Assessment of the spatiotemporal effects of land use changes on runoff and nitrate loads in the Talar River. Water 10:1-19. https://doi.org/10.3390/w10040445

Koirala P, Thakuri S, Joshi S, Chauhan R (2019) Estimation of Soil Erosion in Nepal Using a RUSLE Modeling and Geospatial Tool. https://doi.org/10.3390/geosciences9040147

Li L, Zha Y, Zhang J (2020) Int J Appl Earth Obs Geoinformation Spatially non-stationary effect of underlying driving factors on surface urban heat islands in global major cities. Int J Appl Earth Obs Geoinformation 90:102131. https://doi.org/10.1016/j.jag.2020.102131

Mehri A, Salmanmahiny A, Tabrizi ARM, et al (2018) Investigation of likely effects of land use planning on reduction of soil erosion rate in river basins: Case study of the Gharesoo River Basin. Catena 167:116129. https://doi.org/10.1016/j.catena.2018.04.026

Mirchooli F, Kiani-Harchegani M, Khaledi A (2020a) Spatial distribution dependency of soil organic carbon content to important environmental variables. Ecological Indicators 116:106473. https://doi.org/10.1016/j.ecolind.2020.106473

Mirchooli F, Sadeghi SH, Darvishan AK (2020b) Analyzing spatial variations of relationships between Land Surface Temperature and some remotely sensed indices in different land uses. Remote Sensing Applications: Society and Environment 100359. https://doi.org/10.1016/j.rsase.2020.100359

Mohamadi M, Fallah M, Kavian A, et al (2016) The Application of RUSLE Model in Spatial Distribution Determination of Soil loss Hazard. Ecohydrology 3:645-658 
Mohammadi M, Khaledi Darvishan A, Bahramifar N (2019) Spatial distribution and source identification of heavy metals ( $\mathrm{As}, \mathrm{Cr}, \mathrm{Cu}$, and $\mathrm{Ni}$ ) at sub-watershed scale using geographically weighted regression. International Soil and Water Conservation Research 7:308-315. https://doi.org/10.1016/j.iswcr.2019.01.005

Nazari MZAA, Mohammady SM (2017) Investigating effects of land use change scenarios on soil erosion using CLUE-s and RUSLE models. International Journal of Environmental Science and Technology 14:19051918. https://doi.org/10.1007/s13762-017-1288-0

Nearing MA, Foster GR, Lane L j, Finkner SC (1989) A process-based soil erosion model for USDA water erosion prediction project. Transactions of ASAE. Transactions of the ASAE 32:1587-1593

Nunes AN, Almeida AC De, Coelho COA (2011) Impacts of land use and cover type on runoff and soil erosion in a marginal area of Portugal. Applied Geography 31:687-699. https://doi.org/10.1016/j.apgeog.2010.12.006

Nyesheja EM, Chen X, El-Tantawi AM, et al (2019) Soil erosion assessment using RUSLE model in the Congo Nile Ridge region of Rwanda. Physical Geography 40:339-360. https://doi.org/10.1080/02723646.2018.1541706

Ochoa PA, Fries A, Mejía D, et al (2016) Effects of climate, land cover, and topography on soil erosion risk in a semiarid basin of the Andes. Catena 140:31-42. https://doi.org/10.1016/j.catena.2016.01.011

Park KN (2012) Impacts of Land Use Changes on Soil Erosion in Pa Deng Sub-district, Adjacent Area of Kaeng. Soil \& Water Resources 7:10-17

Pejman A, Nabi Bidhendi G, Ardestani M, et al (2015) A new index for assessing heavy metals contamination in sediments: A case study. Ecological Indicators 58:365-373. https://doi.org/10.1016/j.ecolind.2015.06.012

Prasannakumar V, Shiny R, Geetha N, Vijith H (2011) Spatial prediction of soil erosion risk by remote sensing, GIS and RUSLE approach : a case study of Siruvani river watershed in Attapady valley, Kerala, India. 965-972. https://doi.org/10.1007/s12665-011-0913-3

Renard KG, Foster GR, Weesies GA, Porter JP (1991) RUSLE: Revised universal soil loss equation. Journal of Soil and Water Conservation 46:30-33

Renard KG, Freimund JR (1994) Using monthly precipitation data to estimate the R-factor in the revised USLE. Journal of hydrology 157:287-306

Ruysschaert G, Poesen J, Verstraeten G, Govers G (2007) Soil loss due to harvesting of various crop types in 

https://doi.org/10.1016/j.agee.2006.08.012

Setyawan C, Lee CY, Prawitasari M (2019) Investigating spatial contribution of land use types and land slope classes on soil erosion distribution under tropical environment. Natural Hazards 98:697-718. https://doi.org/10.1007/s11069-019-03725-x

Sharma A, Tiwari KN, Bhadoria PBS (2011) Effect of land use land cover change on soil erosion potential in an agricultural watershed. 789-801. https://doi.org/10.1007/s10661-010-1423-6

Taghipour Javi S, Malekmohammadi B, Mokhtari H (2014) Application of geographically weighted regression model to analysis of spatiotemporal varying relationships between groundwater quantity and land use changes (case study: Khanmirza Plain, Iran). Environmental Monitoring and Assessment 186:3123-3138. https://doi.org/10.1007/s10661-013-3605-5

Tang Q, Xu Y, Bennett SJ (2015) Assessment of soil erosion using RUSLE and GIS : a case study of the Yangou watershed in the Loess Plateau, China. Environmental Earth Sciences 1715-1724. https://doi.org/10.1007/s12665-014-3523-z

Thomas J, Joseph S, Thrivikramji KP (2018) Estimation of soil erosion in a rain shadow river basin in the southern Western Ghats, India using RUSLE and transport limited sediment delivery function. International Soil and Water Conservation Research 6:111-122. https://doi.org/10.1016/j.iswcr.2017.12.001

Thornes JB, others (1990) The interaction of erosional and vegetational dynamics in land degradation: spatial outcomes. Vegetation and Erosion Processes and Environments 41-53

Thornes JB, Wainwright J (2004) Environmental Issues in the Mediterranean: processes and perspectives from the past and present. Routledge

Torabi Haghighi A, Menberu MW, Darabi H, et al (2018) Use of remote sensing to analyse peatland changes after drainage for peat extraction. Land Degradation \& Development 29:3479-3488

Troeh FR, Hobbs JA, Donahue RL, others (1980) Soil and water conservation for productivity and environmental protection. Prentice-Hall, Inc.

Tu J (2011) Spatially varying relationships between land use and water quality across an urbanization gradient explored by geographically weighted regression. Applied Geography 31:376-392. https://doi.org/10.1016/j.apgeog.2010.08.001

Vanacker V, Ameijeiras-mariño Y, Schoonejans J, et al (2019) Land use impacts on soil erosion and 
Wang D, Fu B, Zhao W, et al (2008) Multifractal characteristics of soil particle size distribution under different land-use types on the Loess Plateau, China. 72:29-36. https://doi.org/10.1016/j.catena.2007.03.019

495

496

497

Wang K, Zhang CR, Li WD, et al (2014) Mapping soil organic matter with limited sample data using geographically weighted regression. Journal of Spatial Science 59:91-106. https://doi.org/10.1080/14498596.2013.812024

Wischmeier WH (1976) Use and misuse of the universal soil loss equation. Journal of soil and water conservation

Zare M, Panagopoulos T, Loures L (2017) Simulating the impacts of future land use change on soil erosion in the Kasilian watershed, Iran. Land Use Policy 67:558-572. https://doi.org/10.1016/j.landusepol.2017.06.028

Zerihun M, Mohammedyasin MS, Sewnet D, et al (2018) Assessment of soil erosion using RUSLE, GIS and remote sensing in NW Ethiopia. Geoderma Regional 12:83-90. https://doi.org/10.1016/j.geodrs.2018.01.002

Zhao C, Jensen J, Weng Q, Weaver R (2018a) A Geographically Weighted Regression Analysis of the Underlying Factors Related to the Surface Urban Heat Island Phenomenon. Remote Sensing 10:1-18. https://doi.org/10.3390/rs10091428

Zhao H, Ren Z, Tan J (2018b) The Spatial Patterns of Land Surface Temperature and Its Impact Factors : Spatial Non-Stationarity and Scale Effects Based on a Geographically-Weighted Regression Model. Sustainability 10:1-21. https://doi.org/10.3390/su10072242 


\section{Table Captions:}

Table 1. Results of applying Ordinary Least Squares (OLS) and Geographically Weighted Regression (GWR) for spatial modeling of soil erosion $(n=34)$ for the Talar Watershed, Iran

Table 2. The correlation of variables for the RUSLE Max and Min (P value<0.01) 


\section{Figures Captions:}

Fig. 1 General location of the Talar Watershed in Iran and Mazandaran Province (left) and some important information of the study area (right)

Fig. 2 Flowchart of the methodology adopted for spatial modeling of the relationship between soil erosion factors and land use changes for the Talar Watershed, Iran

Fig. 3 Spatial distribution of the soil erosion factors (top) and the RUSLE estimates (bottom) for the Talar Watershed, Iran

Fig. 4 Dendrogram showing clustering of soil erosion in the sub-watersheds of the Talar Watershed, Iran

Fig. 5 Spatial patterns of local adjusted $R^{2}$ and coefficient for the RUSLE factors obtained from GWR for the Talar Watershed, Iran

Fig. 6 Spatial patterns of local $\mathrm{R}^{2}$ between soil erosion and different land uses obtained from GWR for the Talar Watershed, Iran

Fig 7. Scree plot of the soil erosion resulted from RUSLE with land use and R, K, LS, C, and P factors for the Talar Watershed, Iran

Fig 8. PCA of RUSLE with land use and R, K, LS, C, and P factors for the Talar Watershed, Iran 


\section{Figures}

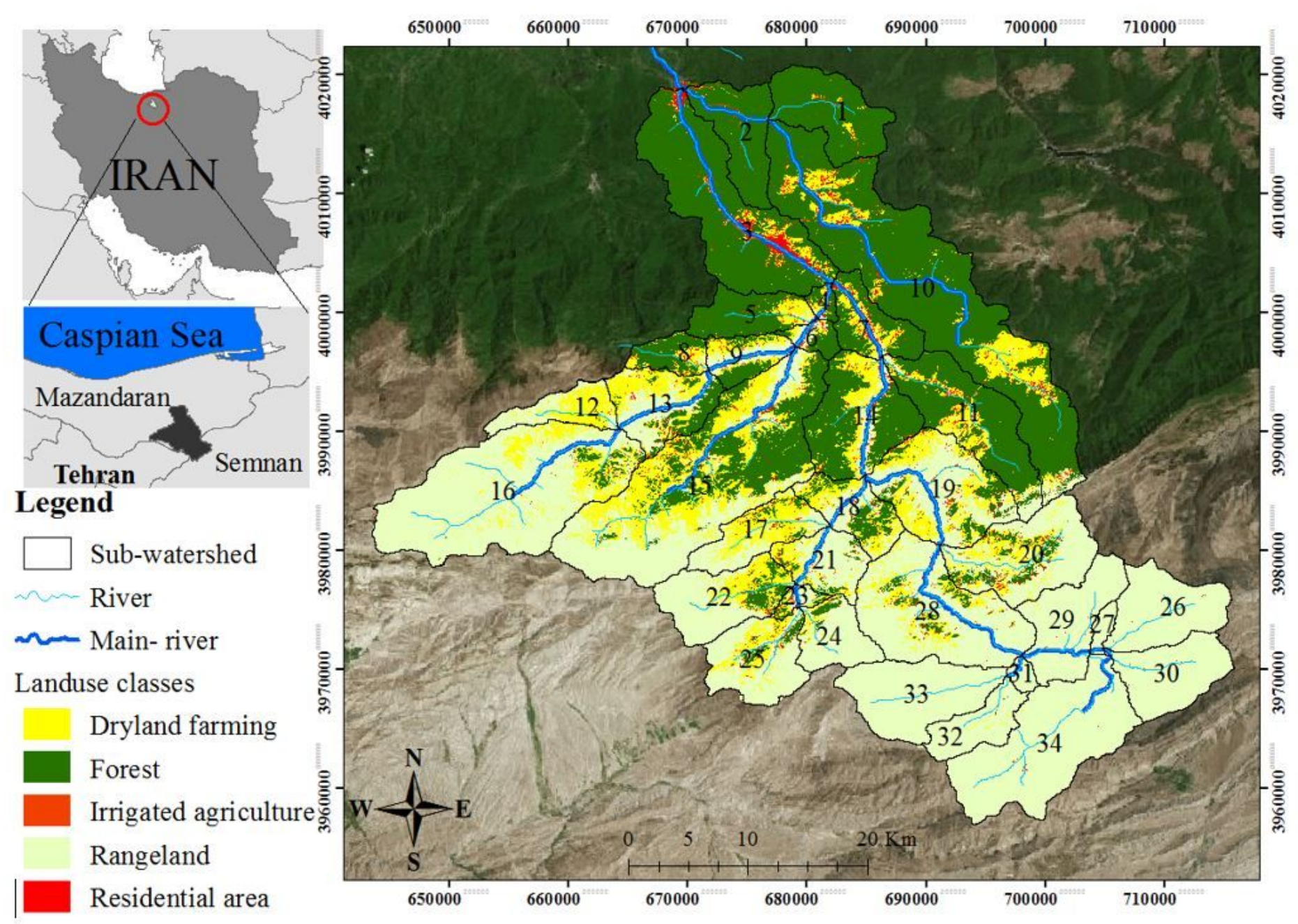

\section{Figure 1}

General location of the Talar Watershed in Iran and Mazandaran Province (left) and some important information of the study area (right) Note: The designations employed and the presentation of the material on this map do not imply the expression of any opinion whatsoever on the part of Research Square concerning the legal status of any country, territory, city or area or of its authorities, or concerning the delimitation of its frontiers or boundaries. This map has been provided by the authors. 


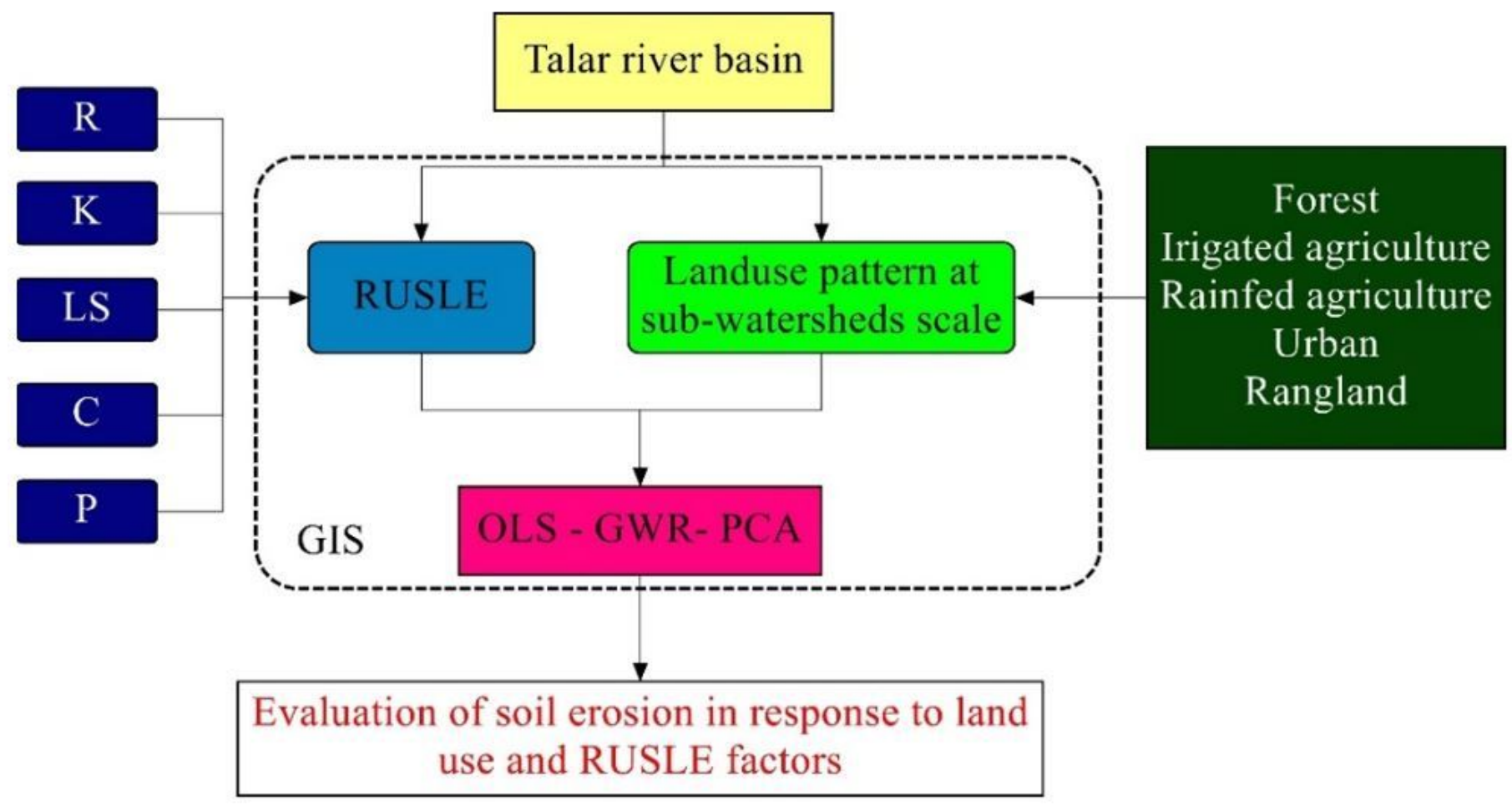

Figure 2

Flowchart of the methodology adopted for spatial modeling of the relationship between soil erosion factors and land use changes for the Talar Watershed, Iran 

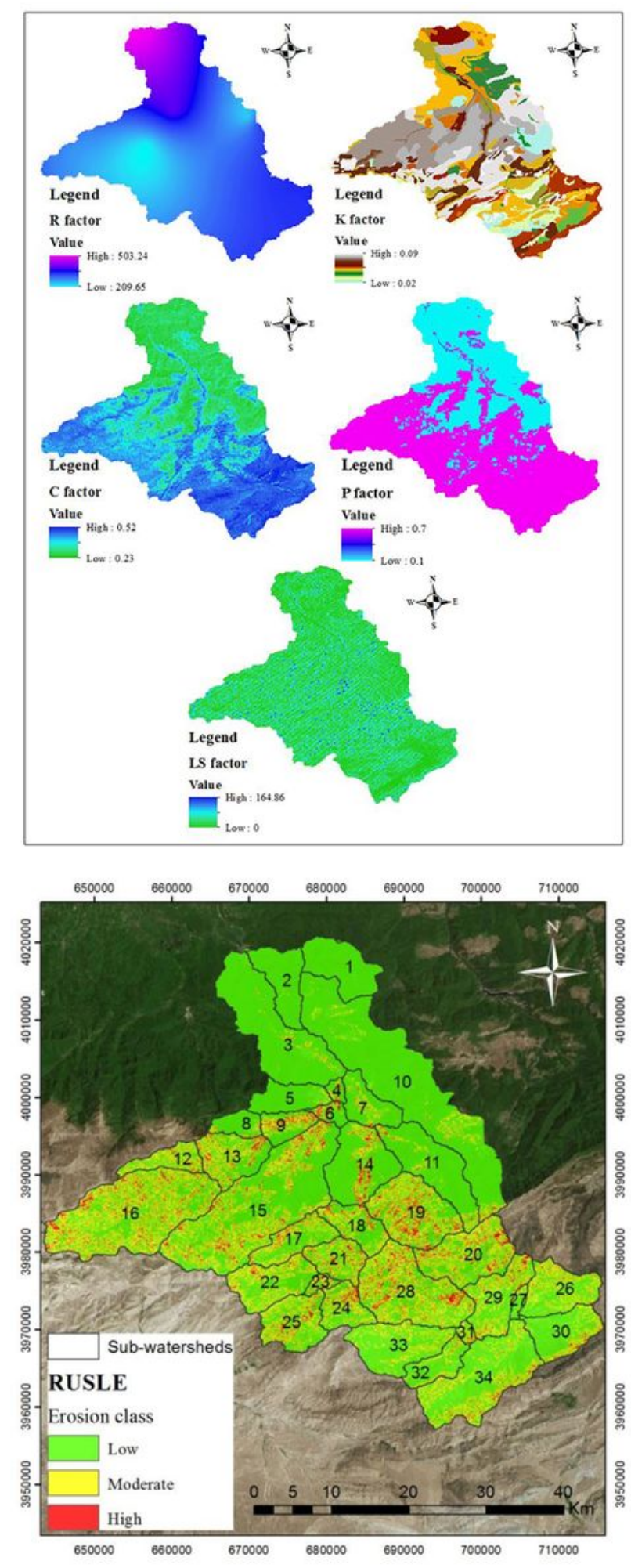

\section{Figure 3}

Spatial distribution of the soil erosion factors (top) and the RUSLE estimates (bottom) for the Talar Watershed, Iran Note: The designations employed and the presentation of the material on this map do not imply the expression of any opinion whatsoever on the part of Research Square concerning the legal status of any country, territory, city or area or of its authorities, or concerning the delimitation of its frontiers or boundaries. This map has been provided by the authors. 
Cluster Dendrogram

9 -

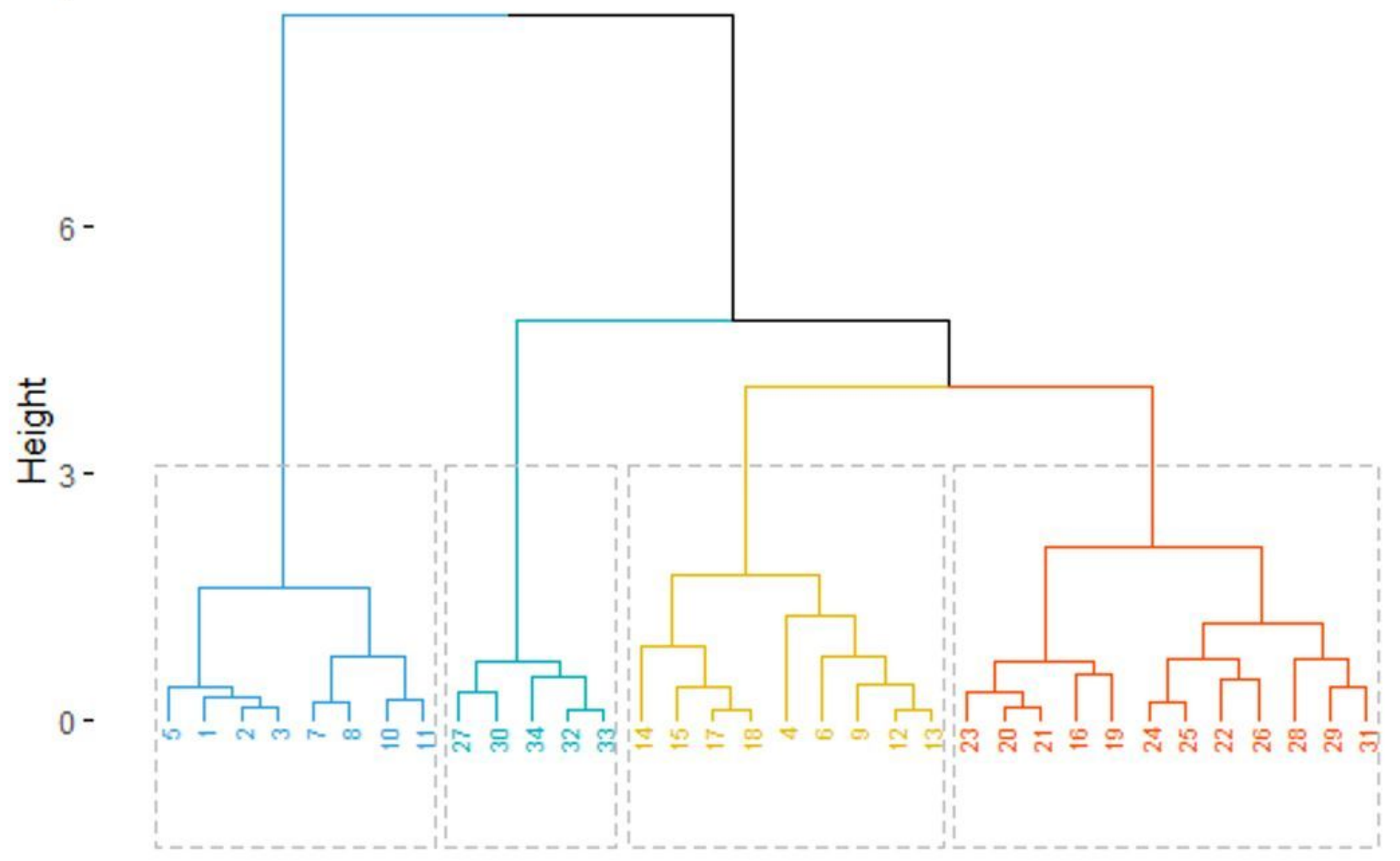

Figure 4

Dendrogram showing clustering of soil erosion in the sub-watersheds of the Talar Watershed, Iran 


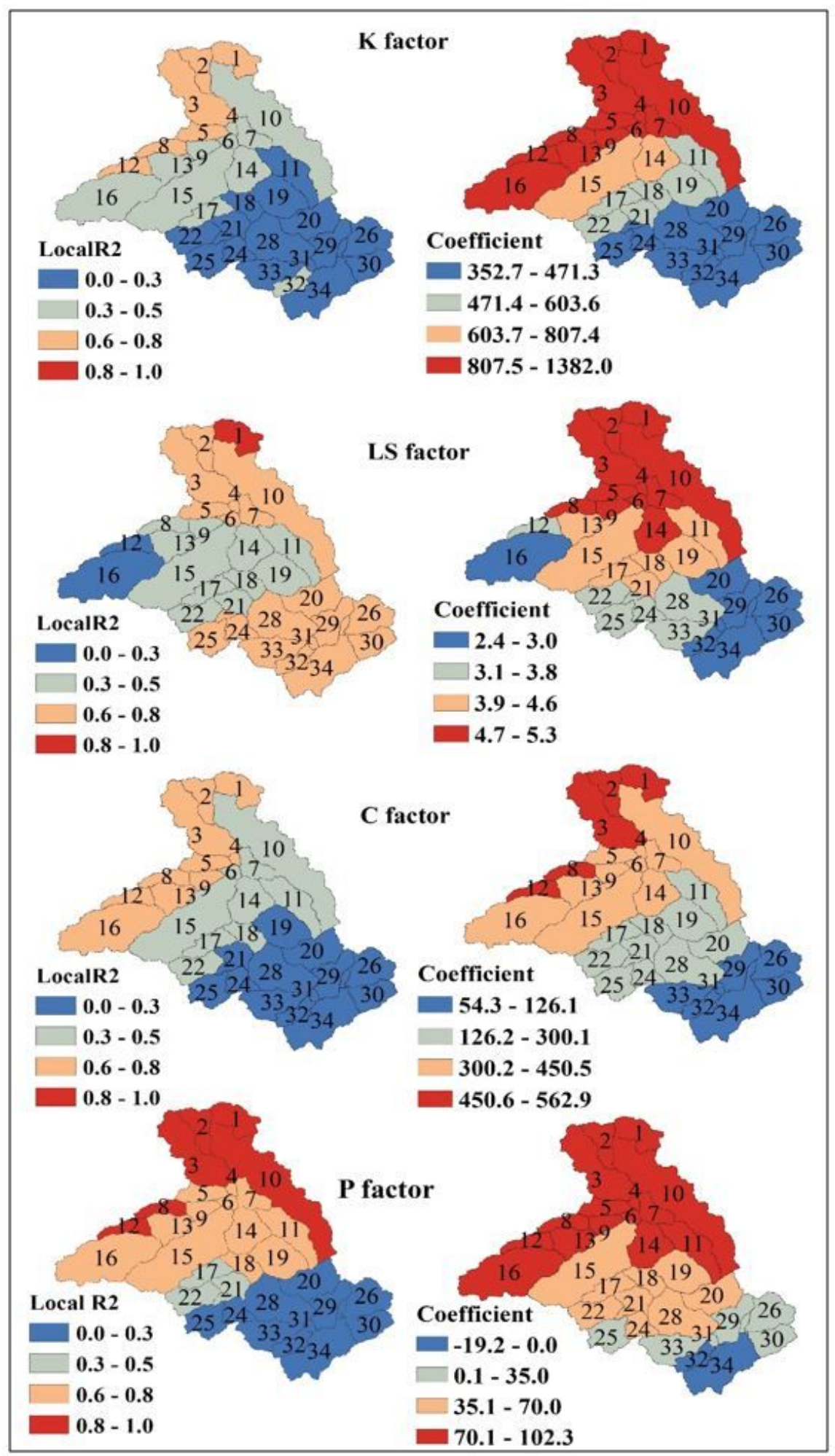

\section{Figure 5}

Spatial patterns of local adjusted R2 and coefficient for the RUSLE factors obtained from GWR for the Talar Watershed, Iran Note: The designations employed and the presentation of the material on this map do not imply the expression of any opinion whatsoever on the part of Research Square concerning the legal status of any country, territory, city or area or of its authorities, or concerning the delimitation of its frontiers or boundaries. This map has been provided by the authors. 


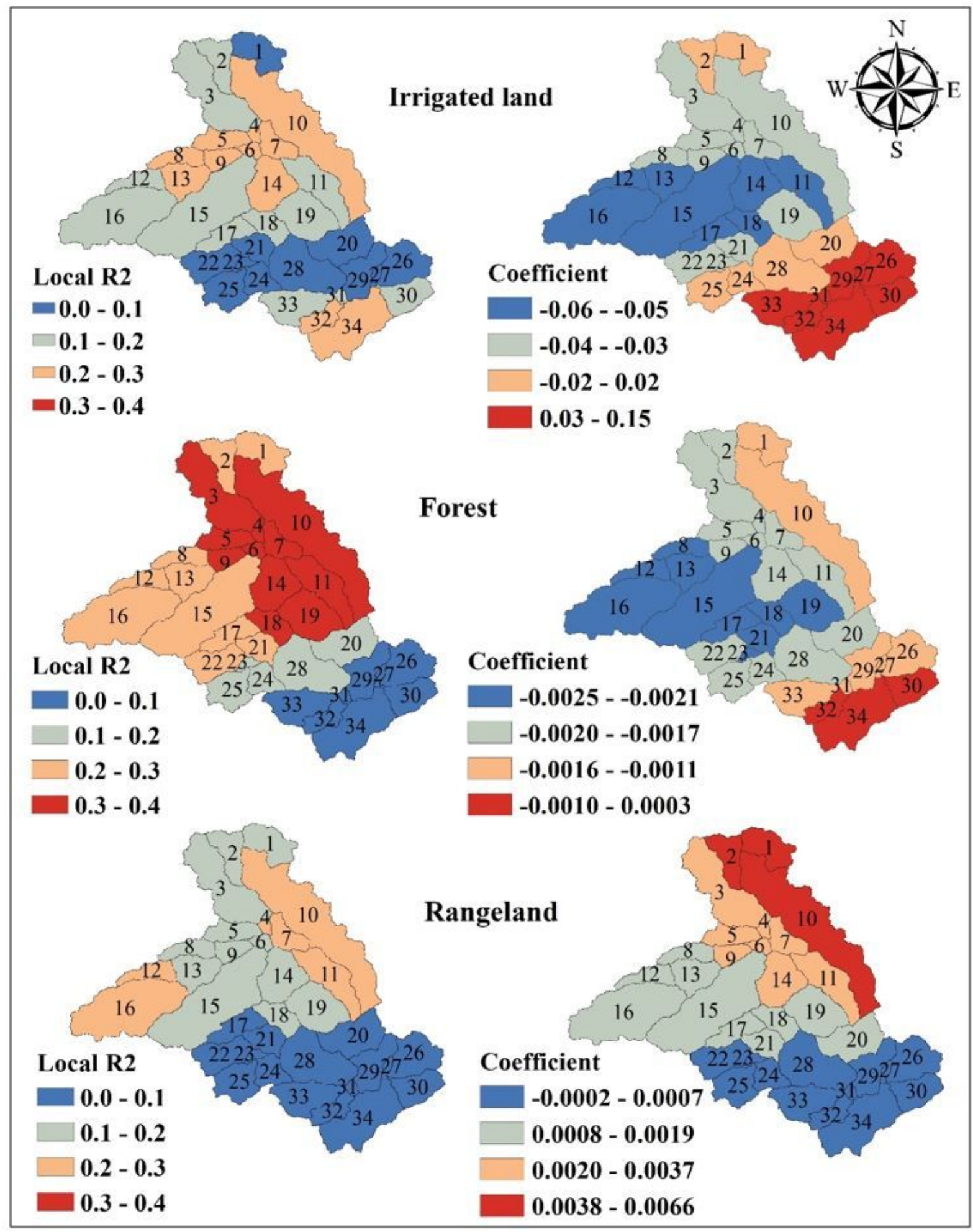

Figure 6

Spatial patterns of local R2 between soil erosion and different land uses obtained from GWR for the Talar Watershed, Iran Note: The designations employed and the presentation of the material on this map do not imply the expression of any opinion whatsoever on the part of Research Square concerning the legal status of any country, territory, city or area or of its authorities, or concerning the delimitation of its frontiers or boundaries. This map has been provided by the authors. 


\section{Scree plot}

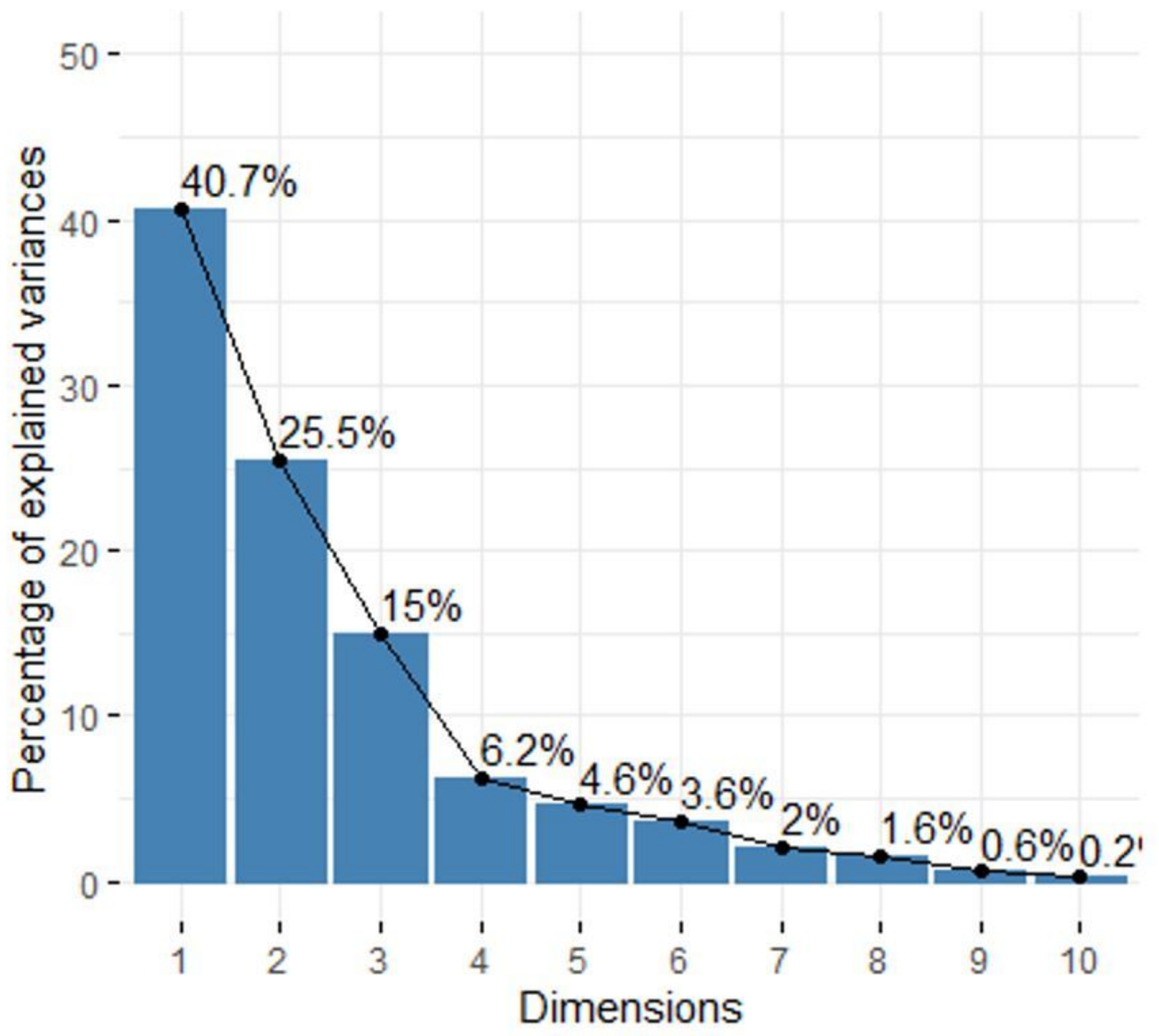

Figure 7

Scree plot of the soil erosion resulted from RUSLE with land use and R, K, LS, C, and P factors for the Talar Watershed, Iran 


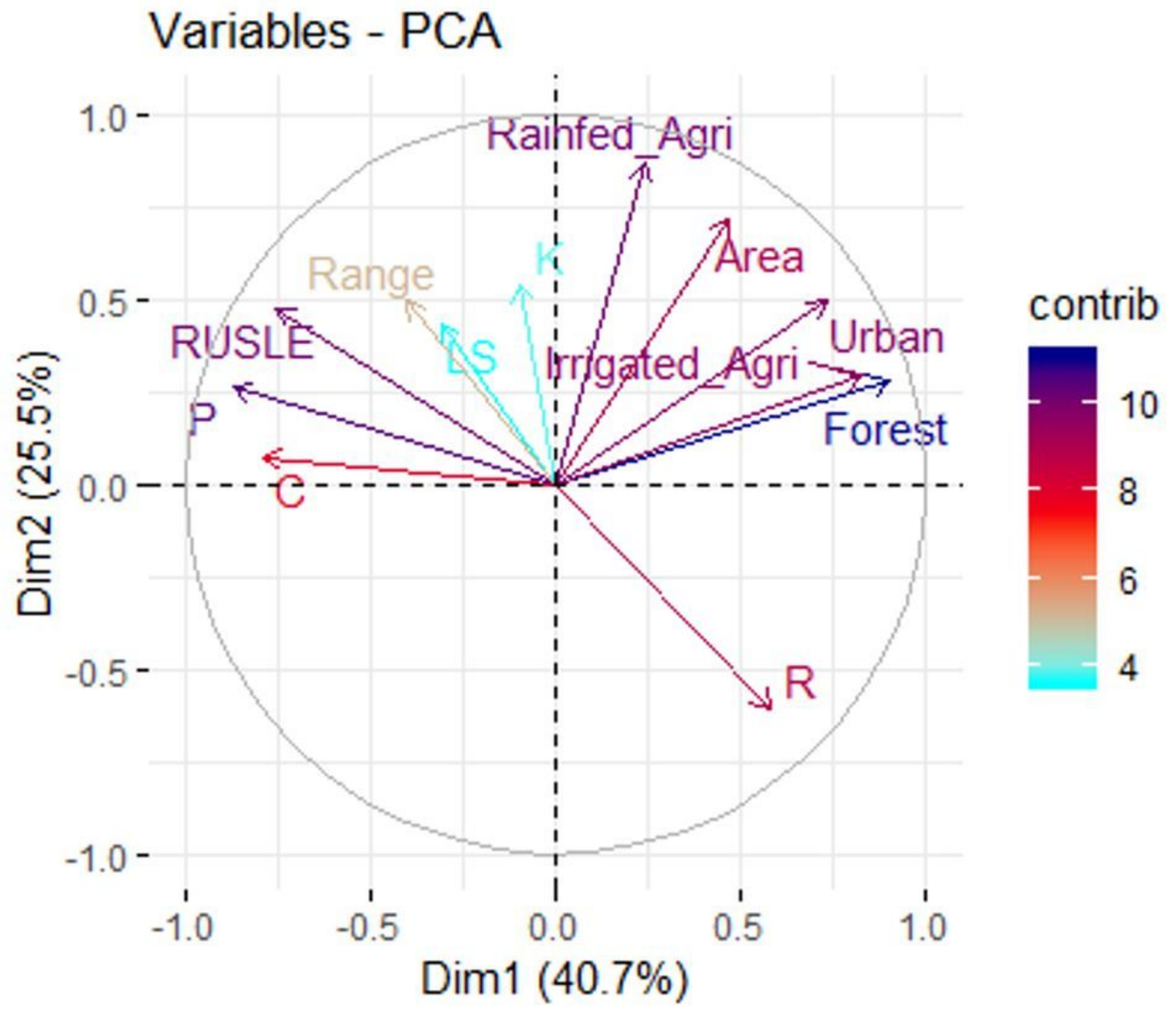

Figure 8

PCA of RUSLE with land use and R, K, LS, C, and P factors for the Talar Watershed, Iran 